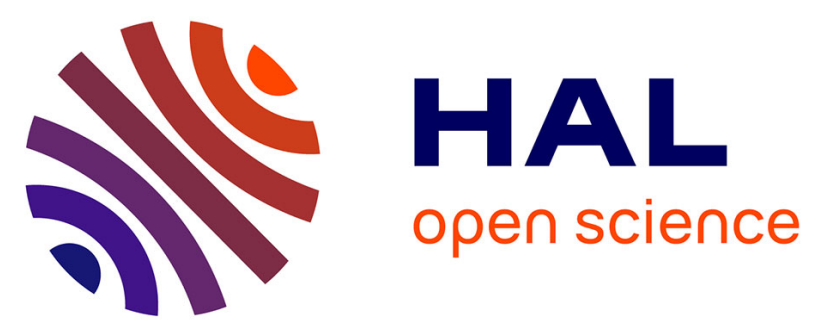

\title{
The NAOMI GAZL multispecies differential absorption lidar: realization and testing on the TADI gas leak simulation facility
}

Jean-Baptiste Dherbecourt, Jean-Michel Melkonian, Antoine Godard, Vincent Lebat, Nicolas Tanguy, Cédric Blanchard, Xavier Watremez, Dominique

Dubucq, Stéphanie Doz, Pierre-Yves Foucher, et al.

\section{To cite this version:}

Jean-Baptiste Dherbecourt, Jean-Michel Melkonian, Antoine Godard, Vincent Lebat, Nicolas Tanguy, et al.. The NAOMI GAZL multispecies differential absorption lidar: realization and testing on the TADI gas leak simulation facility. CLEO 2019, May 2019, SAN JOSE, United States. 10.1364/CLEO_AT.2019.ATh3K.1. hal-02323089

\section{HAL Id: hal-02323089 \\ https://hal.science/hal-02323089}

Submitted on 21 Oct 2019

HAL is a multi-disciplinary open access archive for the deposit and dissemination of scientific research documents, whether they are published or not. The documents may come from teaching and research institutions in France or abroad, or from public or private research centers.
L'archive ouverte pluridisciplinaire HAL, est destinée au dépôt et à la diffusion de documents scientifiques de niveau recherche, publiés ou non, émanant des établissements d'enseignement et de recherche français ou étrangers, des laboratoires publics ou privés. 


\title{
The NAOMI GAZL multispecies differential absorption lidar: realization and testing on the TADI gas leak simulation facility
}

\author{
Jean-Baptiste Dherbecourt ${ }^{1}$, Jean-Michel Melkonian ${ }^{1}$, Antoine Godard ${ }^{1}$, Vincent Lebat ${ }^{1}$, Nicolas Tanguy ${ }^{1}$, \\ Cédric Blanchard ${ }^{1}$, Xavier Watremez ${ }^{2}$, Dominique Dubucq ${ }^{2}$, Stéphanie Doz $^{3}$, Pierre-Yves Foucher ${ }^{3}$, Myriam $^{2}$ \\ Raybaut $^{1+}$ \\ ${ }^{I}$ DPHY, ONERA, Université Paris Saclay, F-91123 Palaiseau, France \\ ${ }^{2}$ TOTAL, France \\ ${ }^{3}$ ONERA/DOTA, Université de Toulouse, F-31055 Toulouse France \\ "myriam.raybaut@onera.fr
}

\begin{abstract}
We report on a differential absorption lidar, designed for remote detection of $\mathrm{CH}_{4}$ and $\mathrm{CO}_{2}$, based on a single-frequency $1.57-1.65 \mu \mathrm{m}$ parametric oscillator/amplifier system. The lidar is tested on a controlled gas release facility. (C) 2019 The Author(s).

OCIS codes: (190.4970) Parametric oscillators and amplifiers; (280.1910) DIAL, differential absorption lidar.
\end{abstract}

\section{Introduction}

Differential absorption lidars (DIAL) are valuable tools for remote detection, localization, and quantification of a gaseous species, for safety applications, as well as for environmental monitoring. DIAL can be tailored to detect species such as $\mathrm{CO}_{2}$ and $\mathrm{CH}_{4}$ in the infrared, where they display characteristic absorption features, linked to their vibration modes. In a DIAL, two laser pulses are emitted, at two wavelengths called ON (tuned to the absorption band) and OFF (on an absorption minimum). The laser pulses are backscattered by atmospheric aerosols, collected by a telescope and focused on a photodetector. A gas plume can be localized and quantified by comparing the range resolved $\mathrm{ON}$ and OFF signals.

Several systems have been and are currently in development for such applications [1,2]. Here, we aim at developing a compact, range resolved, multi-species system for both $\mathrm{CO}_{2}$ and $\mathrm{CH}_{4}$, based a widely tunable, single frequency emitter, with a high conversion efficiency. The emitter is based on a pulsed, nanosecond, single frequency, Nested Cavity Optical Parametric Oscillator (NesCOPO) [3], amplified to $16 \mathrm{~mJ}$, and implemented in a direct detection Lidar system. This Lidar, NAOMI GAZL, is tested on a gas leak tests facility, called TADI for Transverse Anomaly Detection Infrastructure, in the frame of NAOMI project (for New Advanced Observation Method Integration), along with other instruments (for instance hyperspectral imaging).

\section{GAZL instrument}

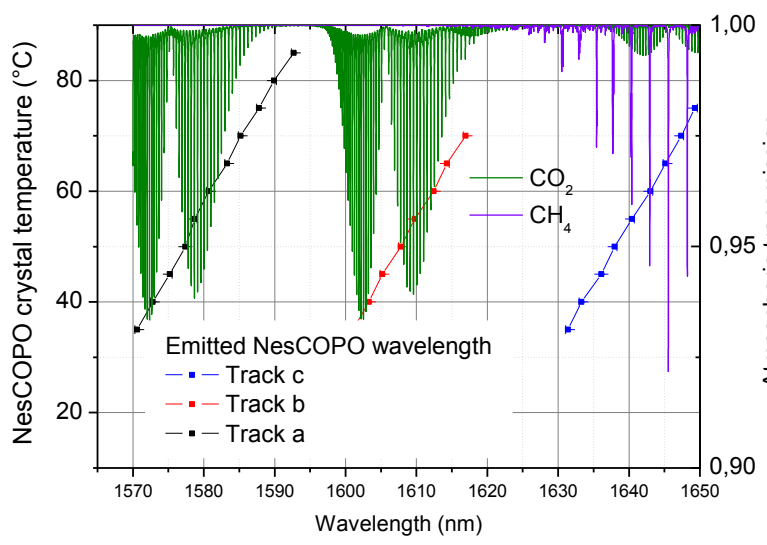

a)
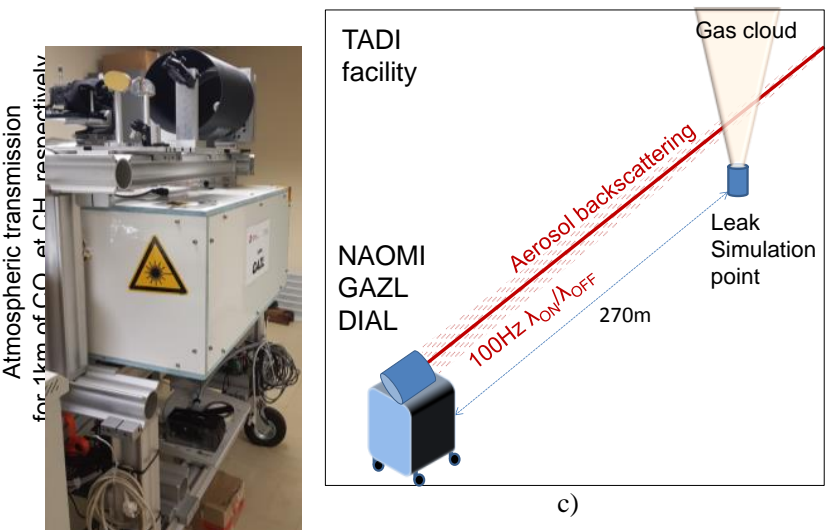

b)

Fig. 1. NAOMI GAZL NesCOPO emitted wavelength as a function of the temperature, for three different PPLN periods a). The atmospheric transmission for $\mathrm{CO}_{2}$ (for $400 \mathrm{ppm}$ ) and $\mathrm{CH}_{4}$ (for $2 \mathrm{ppm}$ ) over $1 \mathrm{~km}$ are given. Picture of the NAOMI GAZL lidar b) and deployment of the Lidar on TADI facility c). 
The emitter is a NesCOPO emitting in the $1.57-1.65 \mu \mathrm{m}$ range, based on a multi-track periodically-poled $\mathrm{LiNbO}_{3}$ (PPLN) crystal, pumped by a $10 \mathrm{~ns}, 100 \mathrm{~Hz}$, injection-seeded Q-switched Nd:YAG laser. Given the wide tunability of the NesCOPO, several absorption lines for $\mathrm{CO}_{2}$ and $\mathrm{CH}_{4}$ can be targeted (Fig.1.a)).

The single frequency radiation is amplified up to $16 \mathrm{~mJ}$, using a PPLN preamplifier and KTA amplifiers. The emitter is then integrated in a DIAL system (Fig.1.b). The receiver unit is a home-build Newtonian telescope, coupled to a commercial amplified PIN photodiode. The maximum achievable detection bandwidth is $14.5 \mathrm{MHz}$, corresponding approximately to $10 \mathrm{~m}$ spatial range resolution cells along the line of sight.

\section{TADI facility}

Located in Lacq in France, TADI facility is an open-air site measuring 2,000 $\mathrm{m}^{2}$ for qualifying systems designed to detect, localize and quantify remotely $\mathrm{CO}_{2}$ and $\mathrm{CH}_{4}$ releases. Equipped with surface facilities (pipelines, columns, recovered wellheads, etc.), this test area can reproduce around 30 scenarios of controlled emissions from 0.3 to $300 \mathrm{~g} / \mathrm{s}$ of gas in an industrial environment.

\section{GAZL testing on TADI facility}

NAOMI GAZL was deployed on the TADI facility during a test campaign in October 2018. The DIAL was located $250 \mathrm{~m}$ away from the gas release system. Fig.2 a) and b) show an example of remote detection, quantification and localization of a $\mathrm{CH}_{4}$ plume generated by TADI. The system was tested for different fluxes of $\mathrm{CH}_{4}$ and $\mathrm{CO}_{2}$. Comparisons with integrated concentration in ppm.m retrieved from LWIR imaging hyperspectral data acquired during this campaign can also be used then to analyse and validate GAZL results (Fig.2 c).

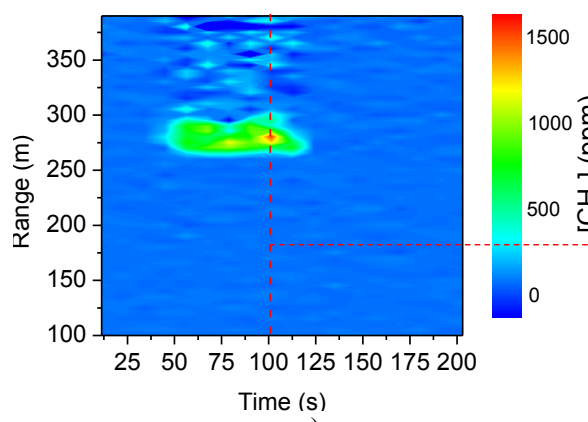

a)

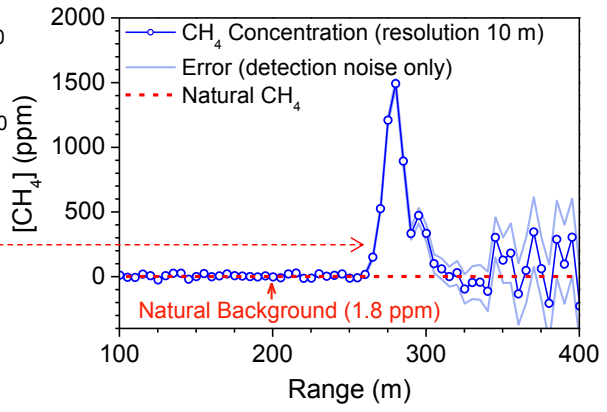

b)

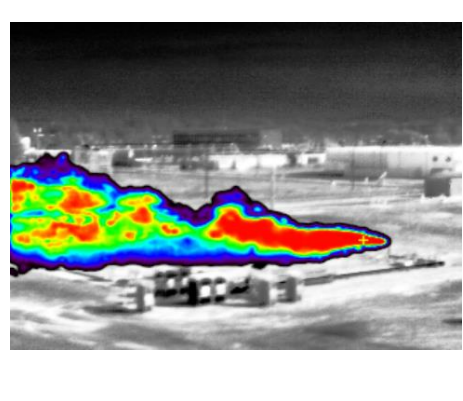

c)

Fig. 2. a) Example of measurement performed using GAZL DIAL, on TADI facility : a gas plume is generated 250m away from the DIAL. The estimated $\mathrm{CH}_{4}$ plume concentration with a $10 \mathrm{~m}$ range resolution and a $10 \mathrm{~s}$ temporal resolution is shown on the left curve. In b), we can see a zoom of the $\mathrm{CH}_{4}$ concentration along the line of sight, with error bars corresponding to the detection noise. c) Methane plume quantitative image (range : 0-200.000 ppm.m) from hyperspectral LWIR data at a distance of $100 \mathrm{~m}$ from the leak with a $5 \mathrm{~s}$ temporal resolution and a $15 \mathrm{~cm}$ spatial resolution.

Further details on the experimental set-up and obtained performances will be given and discussed.

\section{Funding}

This development was carried out in the frame of TOTAL and Onera NAOMI project.

\section{References}

[1] G.A. Wagner, D.L. Plusquellic, Optics Express Vol.26, n¹5,19420-19434 (2018)

[2] A. Amediek, G. Ehret, A. Fix, M. Wirth, C. Büdenbender, M. Quatrevalet, C. Kiemle, and C. Gerbig, Appl. Opt. 56, $5182-5197$ (2017)

[3] A. Godard, M. Raybaut, M. Lefebvre, Encyclopedia of Analytical Chemistry,(2017) 